Journal of Epidemiology and Publich Health (2018), 3(1): 72-82

https://doi.org/10.26911/jepublichealth.2018.03.01.06

\title{
Factors Associated with Women's Decision to Become Commercial Sex Workers in Banjarsari, Surakarta, Central Java
}

\author{
Syefira Ayudia Johar'1), Argyo Demartoto'), C.S.P Wekadigunawan3) \\ 1) Masters Program in Public Health, Universitas Sebelas Maret \\ 2) Faculty of Social and Political Sciences, Universitas Sebelas Maret \\ 3) Faculty of Medicine, Universitas Sebelas Maret
}

\begin{abstract}
Background: In Indonesia, the number of new HIV cases in 2016 was 41.250, and AIDS cases was 7,491. HIV infection predominantly (67.6\%) occur heterosexually. In Central Java, the number of Di Indonesia, new HIV cases in 2016 was 4.032, and AIDS cases was 1.402. Surakarta City has the second highest cases of HIV in Central Java after Semarang District with 38 HIV cases and 46 AIDS cases in September 2017. This study aimed to analyze factors associated with women's decision to become commercial sex workers in Banjarsari.

Subjects and Method: This was an analytical observational study with case control design. The study was conducted in Banjarsari, Surakarta, Central Java. A total sample of 200 study subjects consisting of 100 female commercial sex workers and 100 non sex workers. The dependent variable was women's decision to become commercial sex worker. The independent variables were knowledge of sexually-transmitted disease, family income, pro-commercial sex worker family support, snobbish life style, and access to whore house. The data were collected by questionnaire and analyzed by multiple logistic regression.

Results: Women's decision to become commercial sex worker was negatively associated with good knowledge of sexually-transmitted disease $(\mathrm{OR}=0.03 ; 95 \% \mathrm{CI}=0.01$ to $0.18 ; \mathrm{p}<0.001)$, high family income $(\mathrm{OR}=0.01 ; 95 \% \mathrm{CI}<0.01$ to $0.05 ; \mathrm{p}<0.001)$. Women's decision to become commercial sex worker was positively associated with strong pro-commercial sex worker family support $(\mathrm{OR}=8.15$; 95\% $\mathrm{CI}=2.63$ to $25.23 ; \mathrm{p}<0.001)$, snobbish life style $(\mathrm{OR}=6.20 ; 95 \% \mathrm{CI}=1.81$ to $21.24 ; \mathrm{p}=0.004)$, and access to whore house (OR=8.52; 95\% $\mathrm{CI}=2.49$ to $29.17 ; \mathrm{p}=0.001)$.

Conclusion: Women's decision to become commercial sex worker has negative association with good knowledge of sexually-transmitted disease, high family income. Women's decision to become commercial sex worker has positive association with strong pro-commercial sex worker family support, life style, and access to whore house.
\end{abstract}

Keyword: Women's decision, commercial sex worker, knowledge, family income, family support, life style, access to whore house

\section{Correspondence:}

Syefira Ayudia Johar. Masters Program in Public Health, Universitas Sebelas Maret, Jl. Ir. Sutami 36 A, Surakarta 57126, Central Java. Email: syefira48@gmail.com.

Mobile: +6282136422448 .

$\frac{\text { BACKGROUND }}{\text { In 2030, SDG's expects to be able to stop }}$
the epidemics of HIV/AIDS, Tuberculosis,
Malaria, Hepatitis, water-borne diseases
and other infectious diseases (International

NGO Forum on Indonesian Development, 2016).

All over the world, each day, there are approximately a million of people infected by sexually transmitted diseases (World Health Organization, 2016). Meanwhile, in 
2015, it is estimated that there were about 36.7 millions people infected by HIV and 2.1 millions among the number were recent HIV cases. Some groups which have high risks to get infected by HIV/AIDS are female commercial sex workers, Injection NAPZA consumers, homosexuals, inmates/ criminals, sailors, and some workers in the transportation sector (UNAIDS, 2017). Women working as commercial sex workers are the group with the highest risk to be infected by HIV and they are considered as the significant reason of the new HIV cases increase (Seib et al., 2009). Female commercial sex workers become the significant risk in health sector especially about sexually transmitted diseases (Solomon, Smith and Del Rio, 2008).

In Indonesia, there were 41.250 new HIV cases and 7.491 new AIDS cases in 2016. HIV mostly infects heterosexuals with the percentage of $67.6 \%$. In Central Java, there were 4.032 new HIV cases and 1.402 new AIDS cases in 2016 (Ministry of Health, 2017). Meanwhile, HIV cases in Surakarta is the second highest in Central Java right after Semarang regency with 38 HIV cases and 46 AIDS cases in September 2017 (KPA, 2017).

Female commercial sex workers are women who make money by providing sexual services and consciously decide that it is their occupation (Malakar, 2015). They are categoorized into two, namely direct and indirect workers (Vandepitte, 2006). They usually can be found in some entertainment business such as karaoke places, bars, beauty saloons, and massage parlors.

In Indonesia, sexual transactions done by female commercial sex workers are still considered as illegal. Based on Criminal Code Clause 296, it is stated that whoever deliberately commits some sexual harrashment or eases that kind of activity done by other people and makes it a habit or something which is done regularly, he/she will be sentenced in prison for maximally a year and four months or paying for about fifteen thousands rupiah (Alrianto $M, 2015$ ).

The number of female commercial sex workers estimation is $2.6 \%$ in Asia, $4.3 \%$ in sub-sahara Afrika, and 7.4\% in Latin America (Eileen et al., 2013). The prevalence of female commercial sex workers are mostly in the age between 18-49 years old (Thein, Aung and McFarland, 2015). According to Spiritia foundation (2010), In Indonesia the number of female commercial sex workers was between 177.200 up to 265.000 . The number of customers was even greater which was about $2,435,000$ up to 3,813,000.

The high number of female commercial sex workers is caused by some factors, such as, economical conditions, psychological conditions, the low educational background which makes them easily trapped in the prostitution (Puspitaningtyas, 2016). According to Syamsuddin (2015), the reasons on why some women decided to become commercial sex workers were because it was so easy to access the whore house and also because of the family pressure.

Nuraini (2016) stated some factors that made women become commercial sex workers were economic situations, family, and life style. Okigbo et al., (2014) stated that in Liberia, there were parents who became the reason on why the child became commercial sex workers in order to fulfil the needs of the whole family. There were also some parents who encouraged their daughters to have a relationship with rich older men so that they will easily get the money from them. Ningrum et al., (2014) stated that there were some factors influencing teenagers to become commer- 
cial sex workers. They were: interaction with female commercial sex workers, economic and social conditions, environment, and bad past experiences. Some factors that have relation with how women decided to become commercial sex workers can be described using PRECEDE-PROCEDE theory. According to Ratnaningsih (2016), there were three main factors affecting directly the behaviour and environment which are related to the health problems chosen, namely predisposing factors, enabling factors and reinforcing factors.

According to National AIDS Commission of Surakarta, there were total 561 HIV/AIDS cases from 2005 up to September 2017. There were 39 new HIV cases and 46 new AIDS cases. Meanwhile, the occupation that is risky to cause HIV/ AIDS transmissions is female commercial sex workers as there were 102 HIV cases and 53 AIDS cases. The number of female commercial sex workers in Banjarsari district was 428 .

This study aimed to analyze factors influencing women's decision to become female commercial sex workers in Banjarsari district, Central Java.

\section{Study design}

This was an analytical observational study with case control design. The study was conducted in Banjarsari district, Surakarta in November 2017.

\section{Population and sample}

The population in this study was case population involving all female commercial sex workers in Banjarsari district, Surakarta. The controlled population consisted of all women who were not commercial sex workers in Banjarsari district. The samples were taken using fixed disease sampling.

The inclusion criteria consisted of female commercial sex workers in Banjar- sari district who have worked for about 1-3 months.

\section{Study variables}

The dependent variable was women's decision to become commercial sex workers. The independent variables were the knowledge of sexually transmitted diseases, family incomes, family supports, life style, and access to the whore house.

\section{Operational definition of study variables}

The knowledge of sexually transmitted diseases was defined as all things that the female commercial sex workers know about the diseases. The data were collected by questionnaire. The measurement scale was continuous, but for the purpose of data analysis, it was transformed into dichotomous.

The family income was defined as the total income from all members of the family in a month. The data were collected by questionnaire. The measurement scale was continuous, but for the purpose of data analysis, it was transformed into dichotomous.

Family support was defined as a supportive action and the family acceptance of the women's decision to become commercial sex workers. The data were collected by questionnaire. The measurement scale was continuous, but for the purpose of data analysis, it was transformed into dichotomous.

Life style is about how the female commercial sex workers live their lives in relation to some daily activities. The data were collected by questionnaire. The measurement scale was continuous, but for the purpose of data analysis, it was transformed into dichotomous.

Access to whore house was defined as about how they reach the place to do the sexual transaction based on the hometown, distance, how and how long to get the 
location. The data were collected by questionnaire. The measurement scale was continuous, but for the purpose of data analysis, it was transformed into dichotomous.

Women's decision to be commercial sex workers was defind as a result of someone thinking process until they finally decide to become commercial sex workers. The data were collected by questionnaire. The measurement scale was continuous, but for the purpose of data analysis, it was transformed into dichotomous.

The data were collected using questionnaires. There were also validity and

Table 1. The Result of Reliability Test

\begin{tabular}{lcc} 
Table 1. The Result of Reliability Test & \\
\hline \multicolumn{1}{c}{ Variables } & $\begin{array}{c}\text { Item Total } \\
\text { Correlation (r) }\end{array}$ & Alpha Cronbach \\
\hline STD Knowledge & $\geq 0.21$ & 0.72 \\
Family Support & $\geq 0.22$ & 0.73 \\
Life Styles & $\geq 0.24$ & 0.75 \\
Access to the whore house & $\geq 0.35$ & 0.74 \\
\hline
\end{tabular}

reliability tests on the instruments. Based on the result of item-total correlation reliability test, it was found that the measurement of the knowledge of sexually transmitted diseases, family support, life styles, and access to the whore house variables was $\mathrm{r}$ arithmetic $\geq 0.20$, and the Cronbach's Alpha $\geq 0.70$. Therefore, all the items are proven to be reliable.

\section{Data analysis}

The data analysis techniques were univariate, bivariate, and multivariate anylises. Multivariate analysis was conducted using a multiple logistic regression model.

\begin{tabular}{|c|c|c|c|}
\hline \multicolumn{2}{|l|}{ RESULTS } & \multicolumn{2}{|c|}{ Senior High School (6o\%) and 8o partici- } \\
\hline \multirow{2}{*}{\multicolumn{2}{|c|}{$\begin{array}{l}\text { The charasteristic dimension of } 200 \\
\text { participants were seen from the age of the } \\
\text { female commercial sex workers there were } \\
104 \text { participants who were }<30 \text { years old } \\
(52 \%) \text { and } 96 \text { participants who were } \geq 30 \\
\text { years old }(48 \%) \text {. Among all the partici- } \\
\text { pants, there were } 120 \text { of them who were }< \\
\text { Table 2. The Characteristics of Subjects }\end{array}$}} & \multirow{2}{*}{\multicolumn{2}{|c|}{$\begin{array}{l}\text { pants }(40 \%) \text { attained } \geq \text { Senior High School. } \\
\text { There were } 103 \text { divorced women }(51,5 \%) \\
\text { and } 97 \text { married women }(48.5 \%) \text {. As many } \\
\text { as } 177 \text { women }(88.5 \%) \text { earned } \geq \text { Rp } 50 \text {,ooo. } \\
\text { As many as } 152 \text { participants }(76 \%) \text { had } \\
\text { family members }<2 \text {. }\end{array}$}} \\
\hline & & & \\
\hline Characteristics & Categories & $\mathbf{N}$ & $\%$ \\
\hline \multirow[t]{2}{*}{ Age } & $<30$ years old & 104 & 52 \\
\hline & $\geq 30$ years old & 96 & 48 \\
\hline \multirow[t]{2}{*}{ Educational Background } & $<$ Senior High School & 120 & 60 \\
\hline & $\geq$ Senior High School & 80 & 40 \\
\hline \multirow[t]{2}{*}{ Marital Status } & Widow/Divorced & 103 & 51.5 \\
\hline & Married & 97 & 48.5 \\
\hline \multirow[t]{2}{*}{ Income per day } & $>\operatorname{Rp} 50,000$ & 23 & 11.5 \\
\hline & $\geq \operatorname{Rp} 50,000$ & 177 & 88.5 \\
\hline \multirow{2}{*}{$\begin{array}{l}\text { The number of family } \\
\text { members }\end{array}$} & $<2$ & 119 & 59.5 \\
\hline & $\geq 2$ & 81 & 40.5 \\
\hline
\end{tabular}


Journal of Epidemiology and Publich Health (2018), 3(1): 72-82

https://doi.org/10.26911/jepublichealth.2018.03.01.06

Table 3. The Characteristics of Subject

\begin{tabular}{llcccc}
\hline \multirow{2}{*}{ Characteristics } & \multirow{2}{*}{ Categories } & \multicolumn{2}{c}{ FCSW } & \multicolumn{3}{c}{ NOT FCSW } \\
\cline { 2 - 5 } & & $\mathbf{n}$ & $\mathbf{\%}$ & $\mathbf{n}$ & $\mathbf{\%}$ \\
\hline \multirow{2}{*}{ Age } & $<30$ & 59 & $59 \%$ & 37 & $37 \%$ \\
\multirow{2}{*}{ Educational Background } & $\geq 30$ & 41 & $41 \%$ & 63 & $63 \%$ \\
& ES & 47 & $47 \%$ & 3 & $3 \%$ \\
\multirow{3}{*}{ Marital Status } & JHS & 49 & $49 \%$ & 21 & $21 \%$ \\
& SHS & 4 & $4 \%$ & 76 & $76 \%$ \\
Income per day & Widow/Divorced & 19 & $19 \%$ & 22 & $22 \%$ \\
\multirow{2}{*}{ The number of family } & Married & 81 & $81 \%$ & 78 & $78 \%$ \\
members & $<$ Rp 50,000 & 23 & $23 \%$ & 0 & $0 \%$ \\
& $\geq$ Rp 50,000 & 77 & $77 \%$ & 100 & $100 \%$ \\
& $<2$ & 34 & $34 \%$ & 85 & $85 \%$ \\
\hline
\end{tabular}

Table 3 shows that the group with most members were $<30$ years old (59\%). In the controlled group, mostly they belong to $\geq 30$ years old (41\%). In the case group, most of them were JHS graduates (49\%). In the controlled group, the highest percentage was in the SHS graduates (76\%). For the case group related to the marital status, most of them were widows or divorced women (81\%). Meanwhile, for the control-

Table 4. The Variables Descriptions

\begin{tabular}{lccccc}
\multicolumn{1}{c}{ Variables } & n & Min. & Max. & Mean & DS \\
\hline STD knowledge & 200 & 5 & 15 & 11.29 & 2.67 \\
Family income & 200 & 900,000 & 3,000, ooo & $1,577,500$ & 487,011 \\
Family support & 200 & 2 & 9 & 5.66 & 1.29 \\
Life Styles & 200 & 0 & 14 & 5.84 & 3.58 \\
Access to the whore & 200 & 1 & 6 & 3.68 & 1.18 \\
house & & & & & \\
\hline
\end{tabular}

Table 4 displays each descriptive statistics, namely minimum score, maximum score, mean score and deviation standard. The table is used to measure continous scale variables, both dependent and independent variables. Mean score presents the average score, meanwhile the standard deviation shows how varied the data were. If the score of the deviation standard is low, it means that the data are representative. led group, they were mostly married (78\%). For the case group, in relation to theri income per day, there were mostly $\geq \mathrm{Rp}$ 50,000 (77\%). For the controlled group, they all got $\geq \operatorname{Rp} 50,000$ (100\%). For the case group, in relation to the number of family members, most of the have $\geq 2$ (66\%). Meanwhile for the controlled group, most of them have $<2(85 \%)$.
Table 5 shows the bivariate analysis between knowledge about STD, family income, family support, lifestyle, access to the whore house, and women's decisions to become sex workers.

High knowledge of STD, family income $\geq$ minimum regional wage ( $\mathrm{Rp}$ $1,532,500$ ) lowered the likelihood of a woman makes the decision to become a sex worker.

Families who support their children to become commercial sex workers, glamo- 
rous lifestyle, and access were more likely improved a women to become sex workers.

Table 5. Bivariate analysis of knowledge about STD, family income, family support, lifestyle, and access to the whore house with women's decisions to become sex workers

\begin{tabular}{|c|c|c|c|c|c|c|c|c|}
\hline \multirow{3}{*}{ Variable } & \multirow{3}{*}{ Category } & \multicolumn{4}{|c|}{ Decision to Become FCSW } & \multirow{3}{*}{$\mathbf{O R}$} & \multirow{3}{*}{$95 \%$ CI } & \multirow{3}{*}{$\mathbf{p}$} \\
\hline & & \multicolumn{2}{|c|}{ FCSW } & \multicolumn{2}{|c|}{ Non FCSW } & & & \\
\hline & & $\mathbf{n}$ & $\%$ & $\mathbf{n}$ & $\%$ & & & \\
\hline STD & Low & 65 & $83.3 \%$ & 13 & $16.7 \%$ & 0.08 & 0.04 to 0.16 & $<0.001$ \\
\hline Knowledge & High & 35 & $28.7 \%$ & 87 & $71.3 \%$ & & & \\
\hline \multirow{3}{*}{$\begin{array}{l}\text { Family } \\
\text { Income }\end{array}$} & $<$ Minimum & 87 & $84.5 \%$ & 16 & $15.5 \%$ & 0.03 & 0.01 to 0.06 & $<0.001$ \\
\hline & regional wage & & & & & & & \\
\hline & $\begin{array}{l}\geq \text { Minimum } \\
\text { regional wage }\end{array}$ & 13 & $13.4 \%$ & 84 & $86.6 \%$ & & & \\
\hline Family & Not & 38 & $34.5 \%$ & 72 & $65.5 \%$ & 4.20 & 2.31 to 7.60 & $<0.001$ \\
\hline Support & $\begin{array}{l}\text { Supporting } \\
\text { Supporting }\end{array}$ & 62 & $68.9 \%$ & 28 & $31.1 \%$ & & & \\
\hline Lifestyle & $\begin{array}{l}\text { Good lifestyle } \\
\text { Poor lifestyle }\end{array}$ & $\begin{array}{l}35 \\
65\end{array}$ & $\begin{array}{l}37.2 \% \\
61.3 \%\end{array}$ & $\begin{array}{l}59 \\
41\end{array}$ & $\begin{array}{l}62.8 \% \\
38.7 \%\end{array}$ & 2.67 & 1.51 to 4.74 & 0.001 \\
\hline Acces to the & Near & 40 & $37.7 \%$ & 66 & $62.3 \%$ & 2.91 & 1.64 to 5.18 & $<0.001$ \\
\hline $\begin{array}{l}\text { whore } \\
\text { House }\end{array}$ & Far & 60 & $63.8 \%$ & 34 & $36.2 \%$ & & & \\
\hline
\end{tabular}

Table 6. The results of multiple logistic regression analysis about factors affecting women to become commercial sex workers

\begin{tabular}{lcccc}
\hline \multirow{2}{*}{ Independent variable } & \multirow{2}{*}{ OR } & \multicolumn{2}{c}{ 95\% CI } & \multirow{2}{*}{ p } \\
\cline { 3 - 4 } & & Lower Limit & Upper Limit & $<0.001$ \\
STD Knowledge & 0.03 & 0.01 & 0.05 & $<0.001$ \\
Family Income & 0.01 & 0.00 & 25.23 & $<0.001$ \\
Family Supports & 8.15 & 2.63 & 21.24 & 0.004 \\
Lifestyle & 6.20 & 1.81 & 29.17 & 0.001 \\
Access to the Whore & 8.52 & 2.49 & & \\
House & & & & \\
N observation & 200 & & & \\
-2 log likelihood & 92.46 & & \\
Nagelkerke R2 & $80.4 \%$ & & & \\
\hline
\end{tabular}

Based on a multiple logistic regression, women with high level of knowledge about STD and HIV/AIDS and high family income were less likely to become commercial sex workers.

Women who got strong family support supports from their family to become commercial sex workers $(\mathrm{OR}=8.15$; CI95\%= 2.63 up to 25.23; p<0.001), had glamorous lifestyle $(\mathrm{OR}=6.20$; CI $95 \%=$ 1.81 up to $21.24 ; \mathrm{p}=0.004)$, and easily access the whore house $(\mathrm{OR}=8.52$; CI
$95 \%=2.49$ up to $29.17 ; \mathrm{p}=0.001$ ) were more likely to become commercial sex workers.

\section{DISCUSSION}

In general, findings from this study support the pro-sex work perspective, also known as sex positivism, in that the decision to work as a commercial sex worker was made by themselves. According to the pro-sex work perspective, or sex positivism, autonomous choice of sex work is a woman's right 
(Gerassi, 2015). Advocates of this perspective hold that sexuality, including paid forms, is consensual in many cases and that a woman should be free to make her own decision regarding the type of work in which she chooses to partake (Gerassi, 2015). No sex worker in this study decided to work as a sex worker by force from others.

\section{The relationsip between STD knowledge and women's decisions to become commercial sex workers} The result of this study shows that high knowledge about STD HIV/AIDS decreased the likelihood a women's decisions to become commercial sex workers.

This study is consistent with Mamarodia (2017) that stated that there was a relationship between the knowledge and the prevention of infectious transmitted diseases. The lack of knowledge about STD and the prevention of STD caused a high STD transmission to commercial sex worker. The lack of a proper understanding about sexually transmitted diseases has an impact on the preventive behaviours among women commercial sex workers.

A study by Fatimah (2013), showed that there is a relationship between knowledge and the prevention of STD transmission. Lestari (2010) stated that knowledge about health will affect individual behavior. People with low level of knowledge about STD would affect their health behaviour as well as doing risky sexual activities that will increase the transmission of STD. It is expected that the knowledge about STD will affect someone's decision not to become commercial sex workers.

PRECEDE PROCEED model illustrated that women's decisions to become commercial sex workers was influenced by knowledge about STD, family income, and lifestyle.
This study is consistent with Setyani (2016) and Regar (2016) which stated that individual understanding is influenced by educational. In addition, education also affected the knowledge of commercial sex worker. Individual with higher education will receive more information and knowledge.

\section{The relationship between family income and women's decisions to become commercial sex workers}

The result of this study supports the general assumption that sex workers originate from lower social economic backgrounds (Balfour and Allen, 2014). The current study showed that women who had high family income were less likely to become commercial sex workers than women with low family income.

Findings from this study support the distinction made by UNESCO (2002) that initiation into sex work can be either voluntary or involuntary. According to UNESCO, the former includes women who enter sex work "willingly" because of poverty or family pressure, while the latter includes those who are forced into sex work through trafficking, coercion or traditional practices. Studies from across the world also place sex workers in these two categories. For example in Thailand, broad contextual factors such as the responsibility of women in the household economy, lack of economic development (Wawer et al., 1996).

Wulandari (2017) stated that there was a relationship between family income and the adolescents' reproductive health attitudes. Low socioeconomic status is one among the risk factors of adolescents who do sex before marriage. Socioeconomic status including income, education, and occupation can affect a person's health.

A study by Akbar (2016) using empirical juridical method with in-depth 
interviews to 5 informants in Palu City showed that the factors causing human trafficking to children in Palu were economic factor, parents who give less attention and supervision, and the factors of free sex among children in Palu.

The result of a study by Dasgupta (2013) stated that the poverty among sex workers acted as the reason to become commercial sex workers. Lack of money may also increase the risk factors of sex worker behavior for unsafe sexual activities for monetary gain. The poverty factor was one of the main reasons of risky sexual behavior such as being a commercial sex worker. This study used ethnographic studies and conducted in-depth interviews with CSW in Calcutta, India.

This research used PRECEDE PROCEED by Green and Kreuter. Women's decisions to become commercial sex workers was influenced by predisposing factors such as STD knowledge, family income, and lifestyle.

This study is consistent with Malakar (2015) which stated that poor families cause the sex workers to have risky sexual behaviour. Moreover, lack of job opportunities and high levels of poverty forced them to become commercial sex workers.

As the Marmot Review (2010) recommends, on the prevention of entrance to a sex work, a minimum income for healthy living would ensure appropriate income for all stages of the life course reducing overall levels of poverty, health inequality and improve living standards.

\section{The relationship between family supports and women's decisions to become commercial sex workers}

The result of this study showed that strong family support on women's decisions to become commercial sex workers increased the likelihood of women. Irwansyah (2016) stated that someone who becomes a commercial sex worker was usually supported by her parents or her husband to get money. If a permissive environment has low controls in the community, then the prostitution will increase within the community.

The result of the study by Okigbo et al., (2014) showed that sex transactions among 36 youth at school (ages 13-19) in Monrovia, Liebeiran, reported that parents encouraged their daughters to engage in sex transactions to help their families. This study found that parents encourage young women to do sexual activity with older and potentially wealthy men as an additional source for family income.

This study used PRECEDE PROCEED theory model by Green and Kreuter as the theory of behaviour change. This model theory illustrated women's decisions to become commercial sex workers which was affected by reinforcing factors such as family support. The result of multiple logistic regression stated that there was a positive relationship between knowledge of STD and women's decisions to become commercial sex workers. Therefore, it is necessary to do family approach and provide the information about the bad effects of being commercial sex workers especially for health.

\section{The relationship between lifestyle and women's decisions to become commercial sex workers}

The result of this study showed that poor lifestyle increased women's decisions to become commercial sex workers. Women who have a glamorous lifestyle were more likely to become commercial sex workers than women who do not have a glamorous lifestyle.

According to Micollier (2004), sexuality can provide a consistent site for exploring the various aspects of the social sphere. For example, in Vietnam, commo- 
dification of sexual pleasure had become a sort of lifestyle on the part of the consumer (i.e. men). The activity of consuming pleasure has become the mark of the entrepreneur class, which borrows from Butler's concept of 'performative gender' (1990). In this study, the glamorous lifestyle that is exclusively observable in some segments of the society seems to have tempted some woman to think about becoming a sex worker.

This study is consistent with another study in Indonesia by Ningrum et al., (2014) which stated that glamorous lifestyle is related to modernization so that the teenagers become victims. If teenagers are not able to hold the desire, then they can justify any ways including being commercial sex workers.

The result of a study by Zembe et al. (2013) showed that young women who are involved in sex transactions to meet various needs. Factors that influence the high demand for sex transactions among young women are to have glamorous lifestyle, increased commodity availability, and the widespread use of highly advanced technology. This study used qualitative method with phenomenology using 5 informant.

The result of the study conducted by Husic et al. (2009) showed that lifestyles show the status of "arrogant effect" between respondents who buy luxurious stuffs in an attempt to differentiate themselves with others. Therefore, the sex workers who have glamorous lifestyle wanted to look different from others and seen as successful women. This research used qualitative method with phenomenology using 4 informants.

This study used PRECEDE PROCEED theory model. This theory model illustrated that women's decisions to become commercial sex workers was influenced by predisposing factor such as STD knowledge, family income, and lifestyle. The result of multiple logistic regression stated that there was positive relationship between knowledge about STD and women's decisions to become commercial sex workers. This study is consistent with Zembe et al. (2013) which stated that young women involving in sex transactions were intended to meet various needs. Factors that influence the high demand for sex transactions among young women are to have glamorous lifestyle, increased commodity availability, and the widespread use of highly advanced technology.

\section{The relationship between access to the whore house and women's decisions to become commercial sex workers}

The result of this study showed that access to the whore house increased women's decisions to become commercial sex workers. Andriyani (2013) reported that women who lived in a risky environment (whore house) are more likely to do free sex compared to those who lived in safe social environment.

This study used PRECEDE PROCEED theory model by Green and Kreuter as behaviour change theory. The women's decisions to become commercial sex workers were influenced by enabling factors such as access to the whore house.

This study concludes that women's decision to become commercial sex worker has negative association with good knowledge of sexually-transmitted disease, high family income. Women's decision to become commercial sex worker has positive association with strong pro-commercial sex worker family support, life style, and access to whore house.

\section{REFERENCE}

Alrianto (2015). Kajian Kriminologi Terhadap Praktek Prostitusi. 
Balfour R, Allen J (2014). A Review of the Literature on Sex Workers and Social Exclusion. https://assets.publishing.service.gov.uk/government/uploads/s ystem/uploads/attachment_data/file /303927/A_Review_of_the_Literatu re_on_sex_workers_and_social_excl usion.pdf. Accessed in May 2018.

Dasgupta S (2013). Poverty as a contextual factor affecting sexual health behavior among female sex workers in India, Qualitative Health Research, 23(6): $825-833$.

Eileen (2013). HIV/STI Risk Among Venue-Based Female Sex Workers Across The Globe: A Look Back And The Way Forward, 10: 20-24.

Gerassi L (2015). A Heated Debate: Theoretical Perspectives of Sexual Exploitation and Sex Work. J Sociol Soc Welf. 42(4): 79-100.

Irwansyah L (2016). Kemiskinan, Keluarga dan Prostitusi pada Remaja, Psychology and Humanity, 2: 19-20.

Kementerian Kesehatan RI (2017). Data dan Informasi Profil Kesehatan Indonesia 2016.

Lestari D (2010). Pengaruh Pendidikan Kesehatan Terhadap Pengetahuan Sikap dan Perilaku PSK Dalam Rangka Pencegahan IMS di Lokalisasi Gajah Kumpul Kabupaten, Universitas Sebelas Maret Surakarta.

Malaka (2015). Hazardous Health Behavior of Female Sex Workers: A Case Study, 4(8): 55-59.

Mamarodia (2017). Menular Seksual Pada Siswa Di SMA Dharma Wanita Pineleng: 103-113.

Marmot Review Team (2010). Fair Society, Healthy Lives: Strategic Review of Health Inequalities in England post2010. London: The Marmot Review Team.
Micollier E (2004). Social Significance Of Commercial Sex Work: Implicitly Shaping A Sexual Culture?. Evelyne Micollier. Sexual Cultures in East Asia. The social construction of sexuality and sexual risk in a Time of AIDS, Routledge-Curzon Press, pp.322, 2004, Asian Studies. <halshs01070604>.

Okigbo C (2014). Risk Factors for Transactional Sex among Young Females in Post- Conflict Liberia, African Journal of Reproductive Health Afr J Reprod Health, 18(183): 133-133.

Seib C (2009). Sexually transmissible infections among sex workers and their clients: Variation in prevalence between sectors of the industry, Sexual Health, 6(1): 45-50.

Solomon MM, Smith MJ, Del Rio C (2008). Low educational level: a risk factor for sexually transmitted infections among commercial sex workers in Quito, Ecuador, International Journal of STD \& AIDS, 19(4): 264-267.

Thein ST, Aung T, McFarland W (2015). Estimation of the Number of Female Sex Workers in Yangon and Mandalay, Myanmar, AIDS and Behavior, 1941-1947.

UNAIDS (1997). Kelompok Berisiko Tinggi, 1997.

UNESCO (2002). A Cultural Approach to HIV/AIDS Prevention and Care: Towards a Handbook for India. Studies and Reports Special Series No.16. New Delhi: UNESCO.

Vandepitte $\mathrm{J}$ (2006). Estimates of the number of female sex workers in different regions of the world, Sexually Transmitted Infections, 18-25.

Wawer MJ, Podhisita C, Kanungsukkasem U, Pramualratana A, McNamara R (1996). Origins and working conditions of female sex workers in urban 
Journal of Epidemiology and Publich Health (2018), 3(1): 72-82

https://doi.org/10.26911/jepublichealth.2018.03.01.06

Thailand: Consequences of social context for HIV transmission. Soc. Sci. Med., 42(3): 453-462.

World Health Organization (2017). WHO Sexually transmitted infections (STIs), World Health Organization Website.
Wulandari MJ (2017). Pengaruh Faktor Sosial Ekonomi Rumah Tangga Terhadap Sikap Kesehatan Reproduksi Pada Remaja Fakultas Ekonomi dan Bisnis Universitas Udayana, 1-35. 